\title{
Knockout of endothelin type $B$ receptor signaling attenuates bleomycin-induced skin sclerosis in mice
}

Kengo Akashi', Jun Saegusa', Sho Sendo', Keisuke Nishimura', Takuya Okano ${ }^{2,3}$, Keiko Yagi', Masashi Yanagisawa ${ }^{4}$, Noriaki Emoto ${ }^{2,3}$ and Akio Morinobu ${ }^{1 *}$

\begin{abstract}
Background: Endothelin-1 (ET-1) is important in the pathogenesis of systemic sclerosis (SSC). ET-1 binds two receptors, endothelin type $A\left(E T_{A}\right)$ and endothelin type $B\left(E T_{B}\right)$. Dual $E T_{A} / E T_{B}$ receptor antagonists and a selective $E T_{A}$ receptor antagonist are used clinically to treat SSC, and the effect of these antagonists on fibroblast activation has been described. However, the role of $\mathrm{ET}_{\mathrm{B}}$ receptor signaling in fibrogenesis is less clear. This study was conducted to evaluate the profibrotic function of $\mathrm{ET}_{\mathrm{B}}$ receptor signaling in a murine model of bleomycin (BLM)-induced scleroderma.
\end{abstract}

Methods: We used $E T_{B}$ receptor-knockout $\left(E T_{B} K O\right)$ mice, which are genetically rescued from lethal intestinal aganglionosis by an $\mathrm{ET}_{\mathrm{B}}$ receptor transgene driven by the human dopamine $\beta$-hydroxylase (DßH)-gene promoter, and wild-type mice with $\mathrm{DBH}-\mathrm{ET}_{B}(\mathrm{WT})$. BLM or phosphate-buffered saline (PBS) was administered subcutaneously by osmotic minipump, and skin fibrosis was assessed by dermal thickness, subcutaneous fat atrophy, and myofibroblast count in the dermis. Dermal fibroblasts isolated from $\mathrm{ET}_{B} \mathrm{KO}$ and $\mathrm{WT}$ mice were cultured in vitro, stimulated with BLM or ET-1, and the expression of profibrotic genes was compared by quantitative PCR.

Results: Dermal thickness, subcutaneous fat atrophy, and myofibroblast counts in the dermis were significantly reduced in $\mathrm{ET}_{\mathrm{B}} \mathrm{KO}$ mice compared to $\mathrm{WT}$ mice, after BLM treatment. Compared with wild-type, dermal fibroblasts isolated from $\mathrm{ET}_{\mathrm{B}} \mathrm{KO}$ mice showed lower gene expressions of a-smooth muscle actin and collagen $1 \mathrm{a} 1$ in response to BLM or ET-1 stimulation in vitro.

Conclusions: $\mathrm{ET}-1-\mathrm{ET}_{\mathrm{B}}$ receptor signaling is involved in skin sclerosis and in collagen synthesis by dermal fibroblasts.

Keywords: Systemic sclerosis, Endothelin type B receptor, Dermal fibroblast

\section{Background}

Systemic sclerosis (SSc), a connective-tissue disease of unknown etiology, is characterized by autoimmunity, microvascular impairment, chronic inflammation, and fibrotic changes in the skin and internal organs [1]. The pathogenesis of SSc has been studied in a bleomycin (BLM)-induced scleroderma model [2, 3]. Among fibrotic agents known to contribute to scleroderma, the role of

\footnotetext{
* Correspondence: morinobu@med.kobe-u.ac.jp

${ }^{1}$ Department of Rheumatology and Clinical Immunology, Kobe University Graduate School of Medicine, 7-5-1, Kusunoki-cho, Chuo-ku, Kobe 650-0017, Japan

Full list of author information is available at the end of the article
}

endothelin-1 (ET-1) in SSc fibrosis has been well described [4]. The plasma concentration of ET-1 is elevated in SSc patients, and endothelin receptor expression is increased in the lungs and skin $[5,6]$. ET-1 plays an important role in murine model of BLM-induced scleroderma because endothelin receptor antagonist therapy is reported to attenuate skin fibrosis of mice [4]. Recently, vascular endothelial cell-specific ET-1 knockout mice are also reported to attenuate skin sclerosis [7]. ET-1, which was first characterized as a potent vasoconstrictive peptide derived from endothelial cells, is an important profibrotic mediator that induces the differentiation of fibroblasts to myofibroblasts and increases the extracellular matrix. 
Therefore, ET-1 plays a critical role in vascular impairment and fibrosis in SSc patients.

ET-1 binds two receptor subtypes, the endothelin type $\mathrm{A}\left(\mathrm{ET}_{\mathrm{A}}\right)$ and endothelin type $\mathrm{B}\left(\mathrm{ET}_{\mathrm{B}}\right)$ receptors [8]. Treatment with a dual $\mathrm{ET}_{\mathrm{A}} / \mathrm{ET}_{\mathrm{B}}$ receptor antagonist or a selective $\mathrm{ET}_{\mathrm{A}}$ receptor antagonist improves mortality in patients with pulmonary arterial hypertension [9-11]. $\mathrm{ET}_{\mathrm{A}}$ receptor signaling is critical for dermal fibroblast activation [12]. However, the role of $\mathrm{ET}_{\mathrm{B}}$ receptor signaling in fibrogenesis is less clear.

To investigate the profibrotic activity of the ET-1-ET $\mathrm{B}_{\mathrm{B}}$ receptor signal in fibrosis, we used endogenous $\mathrm{ET}_{\mathrm{B}}$ receptor-knockout $\left(\mathrm{ET}_{\mathrm{B}} \mathrm{KO}\right)$ mice with an $\mathrm{ET}_{\mathrm{B}}$ receptor transgene driven by the human dopamine $\beta$-hydroxylase $(\mathrm{D} \beta \mathrm{H})$ gene promoter, which generated "rescued" $\mathrm{ET}_{\mathrm{B}^{-}}$ knockout mice [13-15]. $\mathrm{ET}_{\mathrm{B}}$-receptor mutant mice and general (not rescued) $\mathrm{ET}_{\mathrm{B}} \mathrm{KO}$ mice, which have aganglionic megacolon and white spotting on the coat, die before reaching adulthood because $\mathrm{ET}_{\mathrm{B}}$ receptor signaling is important in generating melanocytes and enteric neurons [16]. In the "rescued" $\mathrm{ET}_{\mathrm{B}} \mathrm{KO}$ mice, a functional $\mathrm{ET}_{\mathrm{B}}$ receptor is expressed only in the enteric nervous system; other tissues lack $\mathrm{ET}_{\mathrm{B}}$ receptors. These mice survive into adulthood [17].

Here we show that $\mathrm{ET}_{\mathrm{B}} \mathrm{KO}$ mice were resistant to BLM-induced scleroderma, and that compared to WT mice, $\mathrm{ET}_{\mathrm{B}} \mathrm{KO}$ mice showed less fibroblast activation and myofibroblast formation in response to BLM or ET-1.

\section{Methods}

\section{Animals}

The mice were housed in the animal facility of Kobe Pharmaceutical University, with a 12-h dark/light cycle and ad libitum water and food. Heterozygous $\mathrm{ET}_{\mathrm{B}} \mathrm{KO}$ mice $\left(\mathrm{ET}_{\mathrm{B}}+/-\right)$ on a $\mathrm{C} 57 \mathrm{BL} / 6 \mathrm{~J}$ genetic background were generated as described previously $[17,18]$. The human $\mathrm{D} \beta \mathrm{H}$ gene promoter-regulated $\mathrm{ET}_{\mathrm{B}}$ receptor transgene $\left(\mathrm{D} \beta \mathrm{H}-\mathrm{ET}_{\mathrm{B}}\right)$ and $\mathrm{ET}_{\mathrm{B}}+/$ - with $\mathrm{D} \beta \mathrm{H}-\mathrm{ET}_{\mathrm{B}}$ were generated as described previously [13-15]. $\mathrm{ET}_{\mathrm{B}}+/-$ mice were crossed with $\mathrm{D} \beta \mathrm{H}-\mathrm{ET}_{\mathrm{B}}$ mice to obtain three genotypes: wild-type $\mathrm{ET}_{\mathrm{B}}+/+$ with $\mathrm{D} \beta \mathrm{H}-\mathrm{ET}_{\mathrm{B}}$ (WT mice), $\mathrm{ET}_{\mathrm{B}}+/-$ with $\mathrm{D} \beta \mathrm{H}-\mathrm{ET}_{\mathrm{B}}$ (heterozygous $\mathrm{KO}$ mice), and $\mathrm{ET}_{\mathrm{B}^{-}}$- with $\mathrm{D} \beta \mathrm{H}-\mathrm{ET}_{\mathrm{B}}\left(\mathrm{ET}_{\mathrm{B}} \mathrm{KO}\right.$ mice). The $\mathrm{ET}_{\mathrm{B}} \mathrm{KO}$ mice had a partly white coat that distinguished them from heterozygous $\mathrm{KO}$ and WT mice. All experimental protocols were approved by the Ethics Review Committee for Animal Experimentation of Kobe Pharmaceutical University.

\section{Reagents and antibodies}

BLM and ET-1 (H-6995) were purchased from NipponKayaku (Tokyo, Japan) and Bachem (Bubendorf, Switzerland), respectively. Dulbecco's modified Eagle's medium (DMEM) (Nissui-Seiyaku, Tokyo, Japan), RPMI 1640 (Wako Pure Chemical Industries, Osaka, Japan), fetal bovine serum (FBS) (MP Biomedicals, Santa Ana, CA, USA), $1 \%$ penicillin-streptomycin (Lonza, Basel, Switzerland), L-glutamine (Thermo Fisher Scientific, Waltham, MA, USA), and type 1 collagenase (Worthington Biochemical Corporation, Lakewood, NJ, USA) were also used. Bovine serum albumin (BSA), $2 \mathrm{M}$ acetic acid, and dispase were purchased from Sigma-Aldrich (St. Louis, MO, USA). For immunohistochemistry experiments, antialpha smooth-muscle actin ( $\alpha$ SMA) antibody (ab32575), anti-collagen 1 antibody (ab21286), anti-CD3 antibody (ab16669), anti-F4/80 antibody (ab111101) and rabbit polyclonal IgG (ab27472) were purchased from Abcam (Cambridge, UK), and anti-myeloperoxidase antibody (PA5-16672) purchased from Thermo Fisher Scientific (Waltham, MA, USA). A rabbit ABC Staining System (sc-2018) was purchased from Santa Cruz Biotechnology (Dallas, TX, USA).

\section{BLM administration}

BLM was dissolved in phosphate-buffered saline (PBS). BLM or PBS was administered with osmotic minipumps according to previous reports with minor modifications [19-21]. Briefly, osmotic minipumps (Alzet2001; Durect, Cupertino, CA, USA) containing $200 \mu \mathrm{l}$ of BLM (125 mg/ $\mathrm{kg}$ ) or PBS were implanted subcutaneously onto the back of WT or $\mathrm{ET}_{\mathrm{B}} \mathrm{KO}$ mice aged 6-10 weeks; this was counted as day 0 . The pumps delivered $1.0 \mu \mathrm{g} / \mathrm{h}$ for 7 days. The mice were sacrificed on day 28 , and skin and lung tissues were taken. Skin samples were taken a short distance from the osmotic minipump to obtain samples that were not affected by pump implantation.

\section{Histology and immunohistochemistry}

The skin and lung samples were fixed in $4 \%$ paraformaldehyde, embedded in paraffin, sectioned, and stained with Masson's trichrome. To evaluate the BLM-induced scleroderma, we assessed dermal thickening and subcutaneous fat atrophy by measuring the distances between the epidermis and dermis and between the dermis and subcutaneous fat at $40 \times$ magnification. The degree of lung fibrosis was quantified using the Ashcroft score at 40x magnification [22]. Collagen 1 deposition area in the dermis was measured with ImageJ software (National Institutes of Health). Fibroblast activation was assessed by $\alpha \mathrm{SMA}$ immunohistochemical staining of the skin sections, and $\alpha$ SMA-positive myofibroblasts in the dermis were counted at $100 \times$ magnification. To examine whether $\mathrm{ET}_{\mathrm{B}}$ receptor is involved in the inflammation of this model, we counted myeloperoxidase-positive neutrophils, CD3-positive T lymphocytes and F4/80-positive macrophages in the dermis at $100 \times$ magnification.

\section{Collection of bronchoalveolar lavage fluid (BALF)}

To evaluate lung inflammation, a cell count of BALF was performed. Immediately after the mice were sacrificed, a 
20-gauge intravenous catheter was inserted into the trachea. A total of $0.5 \mathrm{ml}$ of PBS was instilled three times and withdrawn from the lung via an intratracheal cannula. After BALF was centrifuged, the pellet was resuspended in $1 \mathrm{ml}$ of PBS. Total BALF cells were counted with a hemocytometer. The BALF solutions were stained with May-Giemsa staining after cytospin centrifuge, and the white blood cell differentiation was evaluated by morphological criteria using a light microscope.

\section{Murine dermal fibroblast isolation and culture}

Dermal fibroblasts were isolated from WT and $\mathrm{ET}_{\mathrm{B}} \mathrm{KO}$ mice at 3-4 weeks of age according to previous reports, with minor modification [23]. Skin samples were placed dermis-down in culture dishes containing RPMI + 3.6\% dispase, and incubated overnight at $4{ }^{\circ} \mathrm{C}$. The dermis was separated from the epidermis, placed in RPMI + $0.05 \%$ type I collagenase, and incubated at $37{ }^{\circ} \mathrm{C}$ for $30 \mathrm{~min}$. The cell suspension was filtered through sterile gauze into a $50-\mathrm{mL}$ conical tube. After adding an equal volume of DMEM $+10 \%$ FBS containing penicillin, streptomycin, and L-glutamine, the suspension was centrifuged at $200 \times \mathrm{g}$ for $10 \mathrm{~min}$. Fibroblasts were resuspended in DMEM + $10 \%$ FBS, plated in 100-mm culture dishes, and incubated at $37{ }^{\circ} \mathrm{C}$ in $5 \% \mathrm{CO}_{2}$ and $95 \%$ room air. For in vitro experiments, fibroblasts were seeded into 6-well plates $\left(1 \times 10^{5}\right.$ per well $)$ and incubated in DMEM $+10 \% \mathrm{FBS}$ at $37{ }^{\circ} \mathrm{C}$ in $5 \% \mathrm{CO}_{2}$. When the fibroblasts had grown to approximately $80 \%$ confluence, the medium was changed and the fibroblasts were treated with $20 \mu \mathrm{g} / \mathrm{ml}$ BLM or $500 \mathrm{nM}$ ET- 1 for $24 \mathrm{~h}$. The BLM was dissolved in DMEM without FBS; the ET1 was dissolved in $0.1 \%$ acetic acid $+0.01 \%$ BSA.

\section{Quantitative real-time polymerase chain reaction (PCR)}

Total RNA was isolated from fibroblasts using an RNeasy Mini kit (Qiagen, Hilden, Germany), followed by cDNA synthesis using a QuantiTect Reverse Transcription kit (Qiagen). PCR reaction mixtures were prepared using the QuantiTect SYBR Green PCR kit (Qiagen), followed by quantitative PCR on a PikoReal system (Thermo Fisher Scientific). The following primer pairs were used: collagen 1 $\alpha 1$ (Col1 $\alpha 1$ ), 5'TGACTGGAA GAGCGGAGAGTACT-3' (forward) and 5'-GGTCTGA CCTGTCTCCATGTTG-3' (reverse); $\alpha S M A, \quad 5$ '-AGA GACTCTCTTCCAGCCATC-3' (forward) and 5'GACGTTGTTAGCATAGAGATC-3' (reverse); ET-1, 5'GTGTCTACTTCTGCCACCTGGACAT-3' (forward) and 5'-GGGCTCGCACTATATAAGGGATGAC-3' (reverse); endothelin receptor type A (EDNRA), 5'-CCTTAT CTSCGTGGTCATTG-3' (forward) and 5'-ACTGAGAG CACAGAGGTTC-3' (reverse); endothelin receptor type $B$ (EDNRB), 5'-GGAATCACAGTGCTGAGTC-3' (forward) and 5'-CTTTGTAGTCCGACGTAATC-3' (reverse); glyceraldahyde-3-phosphate dehydrogenase (GAPDH), 5' AACTTTGGCATTGTGGAAGG-3' (forward) and 5'ACACATTGGGGGTAGGAACA-3' (reverse). GAPDH was used as an internal control to normalize the amount of loaded, complementary DNA (cDNA).

\section{Measurement of soluble collagen content}

Sircol collagen assay (Biocolor Ltd., Belfast, Northern Ireland) was used to quantify soluble collagen contents in fibroblast culture supernatant according to the manufacturer's instructions with minor modification. Briefly, $200 \mu \mathrm{l}$ of supernatant was mixed with $1 \mathrm{ml}$ of Sircol dye reagent for 30 minutes. After centrifugation, the pellets were dissolved in $1 \mathrm{ml}$ Sircol alkali reagent and vortexed. Relative absorbance was measured at $540 \mathrm{~nm}$.

\section{Statistical analysis}

Data are presented as mean \pm standard error of the mean (SEM). Differences between groups were analyzed by Student's $t$ test using GraphPad Prism 5 software (GraphPad Software Inc., La Jolla, CA, USA) and $p<$ 0.05 was considered statistically significant.

\section{Results \\ $\mathrm{ET}_{\mathrm{B}} \mathrm{KO}$ mice resisted $\mathrm{BLM}$-induced scleroderma}

WT and $\mathrm{ET}_{\mathrm{B}} \mathrm{KO}$ mice were treated with BLM or PBS by osmotic minipump. No mice died due to the osmotic minipump implantation or BLM administration. To examine the biological significance of $\mathrm{ET}_{\mathrm{B}}$ receptor signaling after BLM administration, we measured bodyweight changes from day 0 to day $28 . \mathrm{ET}_{\mathrm{B}} \mathrm{KO}$ mice were smaller than WT mice of the same age, and $\mathrm{ET}_{\mathrm{B}} \mathrm{KO}$ mice gained less body weight than did WT mice when treated with PBS. However, while BLM-treated WT mice did not gain body weight, BLM-treated $\mathrm{ET}_{\mathrm{B}} \mathrm{KO}$ mice gained weight similarly to the PBS-treated $\mathrm{ET}_{\mathrm{B}} \mathrm{KO}$ mice (Fig 1b).

To determine the $\mathrm{ET}_{\mathrm{B}}$ receptor's role in BLM-induced scleroderma, skin specimens were obtained from each group on day 28 after implanting the osmotic minipump. The skin samples were stained with Masson's trichrome to evaluate the dermal thickness and subcutaneous fat atrophy. In WT mice, BLM treatment increased the distance between the epidermis and dermis, and reduced the distance between the dermis and subcutaneous fat. In contrast, these distances did not change significantly in the $\mathrm{ET}_{\mathrm{B}} \mathrm{KO}$ mice treated with PBS or BLM (Fig. 2a-c). Likewise, collagen 1 deposition area in the dermis was increased by BLM-treatment in WT mice, but the increment was not seen in $\mathrm{ET}_{\mathrm{B}} \mathrm{KO}$ mice (Fig. 2d). These results suggested that $\mathrm{ET}_{\mathrm{B}}$ receptor signaling is associated with BLM-induced skin sclerosis. Also lung fibrosis and inflammation were evaluated, but neither cell counts in BALF nor lung histological scores were not significantly 


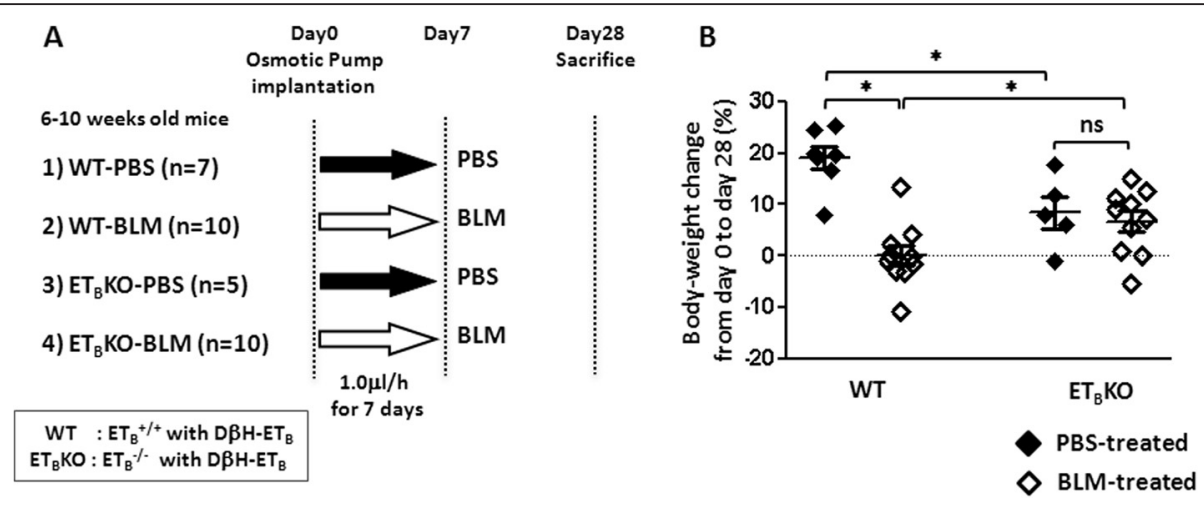

Fig. 1 Study design and body-weight changes of each mice group after BLM treatment. a Summary of this experimental model and sample number of each group. Osmotic pumps containing $200 \mu \mathrm{l}$ of BLM $(125 \mathrm{mg} / \mathrm{kg})$ or PBS were implanted subcutaneously onto the back of WT or $\mathrm{ET}_{\mathrm{B}} \mathrm{KO}$ mice on day 0. Pumps deliver their contents $1.0 \mu \mathrm{g} / \mathrm{h}$ for 7 days. Mice were sacrificed on day 28 . $\mathbf{b}$ Body-weight changes from day 0 to day 28 in $\mathrm{WT}$ and $\mathrm{ET}_{\mathrm{B}} \mathrm{KO}$ mice. The body-weight change was calculated as [(body weight on day 28) - (body weight on day 0$)$ ] $\times$ (body weight on day 0$)^{-1} \times 100(\%)$. Each dot indicates the body-weight change in an individual mouse $\left({ }^{*} p<0.05\right)$. BLM bleomycin, $D \beta H-E T_{B}$ endothelin type $B$ receptor transgene driven by the human dopamine $\beta$-hydroxylase gene promoter, $E T_{B} K O$ endothelin type $B$ receptor knockout, $P B S$ phosphatebuffered saline, WT wild-type

different between WT and $\mathrm{ET}_{\mathrm{B}} \mathrm{KO}$ with BLM treatment (Additional file 1: Figure S1).

\section{Inhibited fibroblast activation protects $\mathrm{ET}_{\mathrm{B}} \mathrm{KO}$ mice against BLM-induced scleroderma}

BLM-induced scleroderma is associated with the differentiation of fibroblasts into myofibroblasts. These myofibroblasts, which are identified by $\alpha$ SMA expression, promote fibrosis by producing collagen and other extracellular matrix components [24, 25].

To determine whether $\mathrm{ET}_{\mathrm{B}}$ receptor signaling contributes to BLM-induced fibroblast differentiation, we counted the number of $\alpha$ SMA-positive cells in the dermis of BLM- or PBS-treated WT and $\mathrm{ET}_{\mathrm{B}} \mathrm{KO}$ mice. BLM increased the number of $\alpha$ SMA-positive myofibroblasts in the WT but not $\mathrm{ET}_{\mathrm{B}} \mathrm{KO}$ dermis, indicating that $\mathrm{ET}_{\mathrm{B}}$ is involved in myofibroblast formation (Fig. 3).

Inflammatory cell filtration in the dermis was counted to determine whether the degree of inflammation was different between WT and $\mathrm{ET}_{\mathrm{B}} \mathrm{KO}$ skin fibrosis. The numbers of myeloperoxidase-positive neutrophils, CD3positive $\mathrm{T}$ cells and F4/80-positive macrophages in the dermis were significantly increased when treated with BLM. However, the numbers of these inflammatory cells

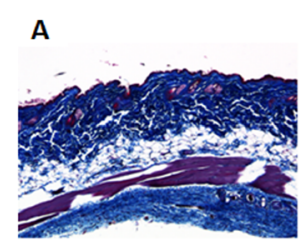

WT-PBS

B

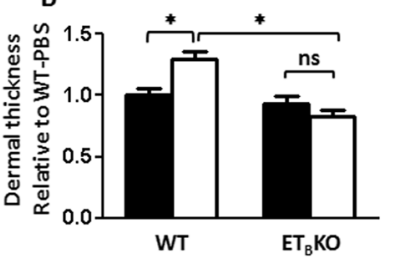

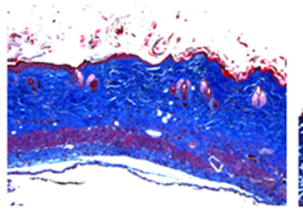

WT-BLM

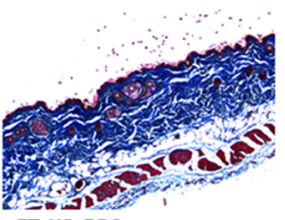

$\mathrm{ET}_{\mathrm{B}} \mathrm{KO}$-PBS

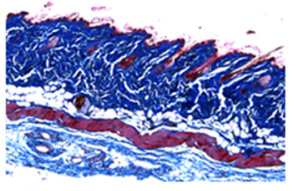

$\mathrm{ET}_{\mathrm{B}} \mathrm{KO}-\mathrm{BLM}$
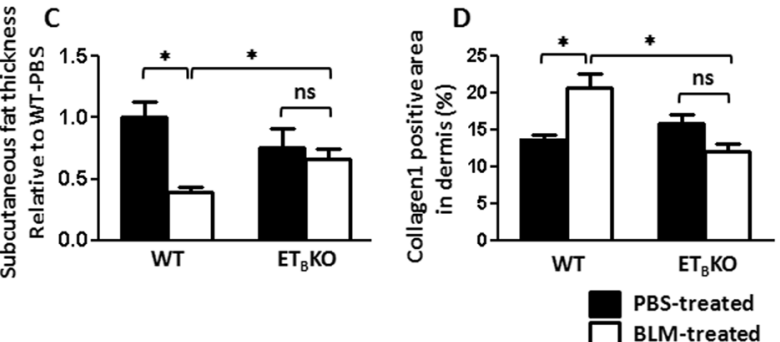

Fig. $2 \mathrm{ET}_{B} \mathrm{KO}$ mice resist BLM-induced skin sclerosis. a Representative images of dermis sections stained with Masson's trichrome at 40x magnification. b Changes in dermal thickness (epidermal-dermal distance) and c subcutaneous fat atrophy (dermal-subcutaneous fat distance) in BLM- or PBStreated $\mathrm{WT}$ and $\mathrm{ET}_{\mathrm{B}} \mathrm{KO}$ mice; values are shown as the mean fold change from PBS-treated WT (WT-PBS) mice. $\mathbf{d}$ Collagen 1 deposition area in dermis of each mice group. ( $\left.{ }^{*} p<0.05\right)\left(n=5-10\right.$ mice per group). BLM bleomycin, $E T_{B} K O$ endothelin type $B$ receptor knockout, $P B S$ phosphate-buffered saline, WT wild-type 


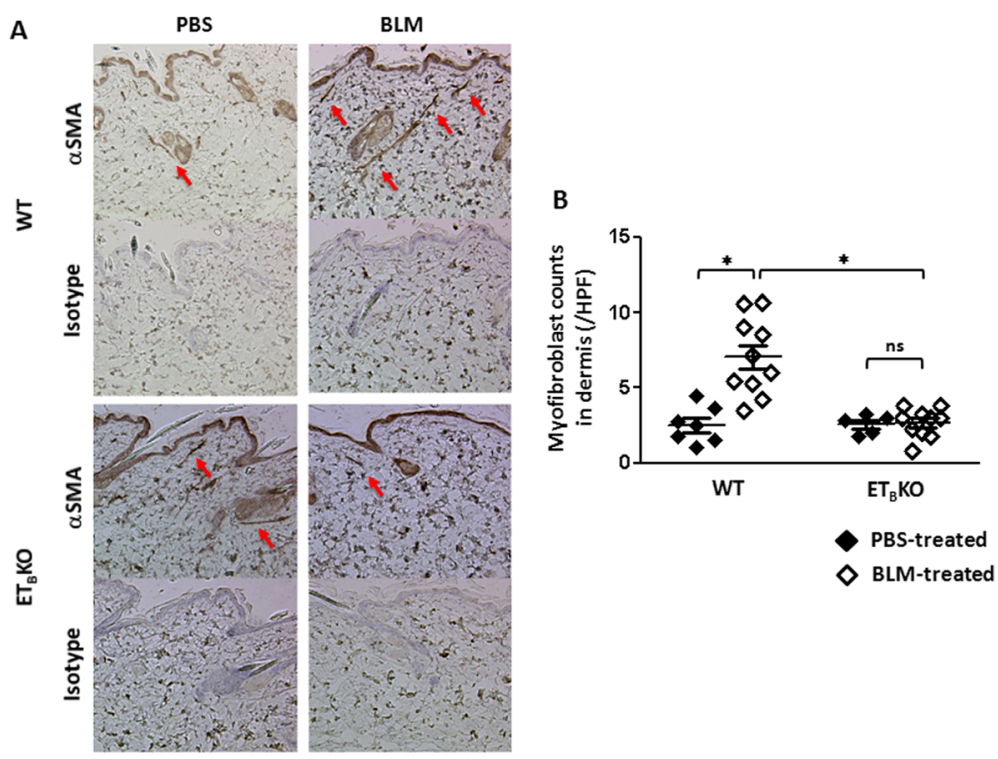

Fig. 3 Fewer aSMA-expressing myofibroblasts are observed in the dermis of $\mathrm{ET}_{\mathrm{B}} \mathrm{KO}$ than $\mathrm{WT}$ mice after BLM treatment. a Representative images showing the immunohistochemical staining of skin samples for aSMA (upper) and isotype (lower) at 100x magnification. Red arrows indicate myofibroblasts (aSMA-expressing spindle-shaped cells). $\mathbf{b}$ Average myofibroblast counts per field of view in the dermis, counted at 100X magnification ( $~ p<0.05$ ); $n=5-10$ mice per group. BLM bleomycin, HPF high-power field, $E T_{B} K O$ endothelin type $B$ receptor knockout, $P B S$ phosphate-buffered saline, WT wild-type

were not different between $\mathrm{WT}$ and $\mathrm{ET}_{\mathrm{B}} \mathrm{KO}$ mice both before and after BLM treatment (Fig. 4).

Collectively $\mathrm{ET}_{\mathrm{B}}$ receptor signaling seemed to contribute to fibroblast activation independent of inflammation.

\section{The $\mathrm{ET}_{\mathrm{B}}$ receptor is associated with dermal fibroblast} activation and collagen synthesis in response to BLM or ET-1 Because fibroblasts play a critical role in fibrosis, we next examined the characteristics of dermal fibroblasts from WT and $\mathrm{ET}_{\mathrm{B}} \mathrm{KO}$ mice. ET-1 or BLM stimulation is reported to induce fibroblasts to express profibrotic genes $[12,26]$. Thus, we isolated dermal fibroblasts from WT and $\mathrm{ET}_{\mathrm{B}} \mathrm{KO}$ mice and assessed their activation and collagen synthesis in response to ET-1 or BLM in vitro.
Dermal fibroblasts from $\mathrm{ET}_{\mathrm{B}} \mathrm{KO}$ mice expressed little or no EDNRB mRNA but expressed EDNRA normally, as expected (Fig. 5a, b).

BLM stimulation induced Coll $\alpha 1$ and ET-1 gene expression in fibroblasts from WT mice, but not in those from $\mathrm{ET}_{\mathrm{B}} \mathrm{KO}$ mice. When stimulated with BLM, WT fibroblasts expressed the $\alpha S M A$ gene at significantly higher levels than did $\mathrm{ET}_{\mathrm{B}} \mathrm{KO}$ fibroblasts (Fig. 5c-e).

ET-1 stimulation induced Col1 $\alpha 1$ expression in WT fibroblasts. ET-1 also tended to induce $\alpha S M A$ mRNA in WT fibroblasts, although this increase did not reach statistical significance. ET-1 stimulation did not influence the Col1 $\alpha 1$ or $\alpha S M A$ expression in $\mathrm{ET}_{\mathrm{B}} \mathrm{KO}$ fibroblasts (Fig. 6a, b).
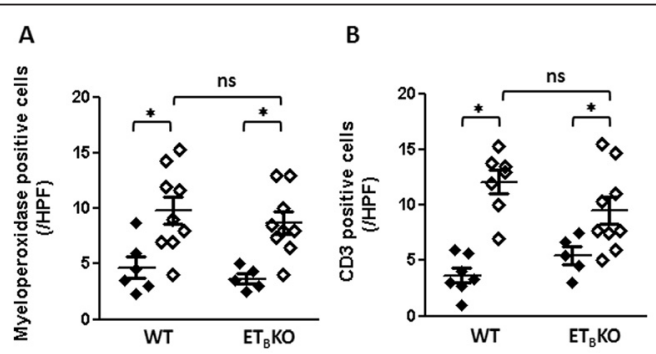

\section{c}

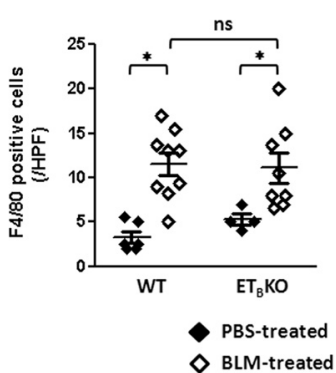

Fig. 4 Infiltration of inflammatory cells in the dermis of $W T$ and $E T_{B} K O$ mice after BLM treatment. The average cell counts of a myeloperoxidase, b CD3, and c F4/80-positive cells in the dermis. The cells were counted per field of view at 100x magnification; $\mathrm{n}=5-10$ mice per group. $\left.{ }^{*} p<0.05\right)$. $B L M$ bleomycin, $E T_{B} K O$ endothelin type B receptor knockout, HPF high-power field, PBS phosphate-buffered saline, WT wild-type 

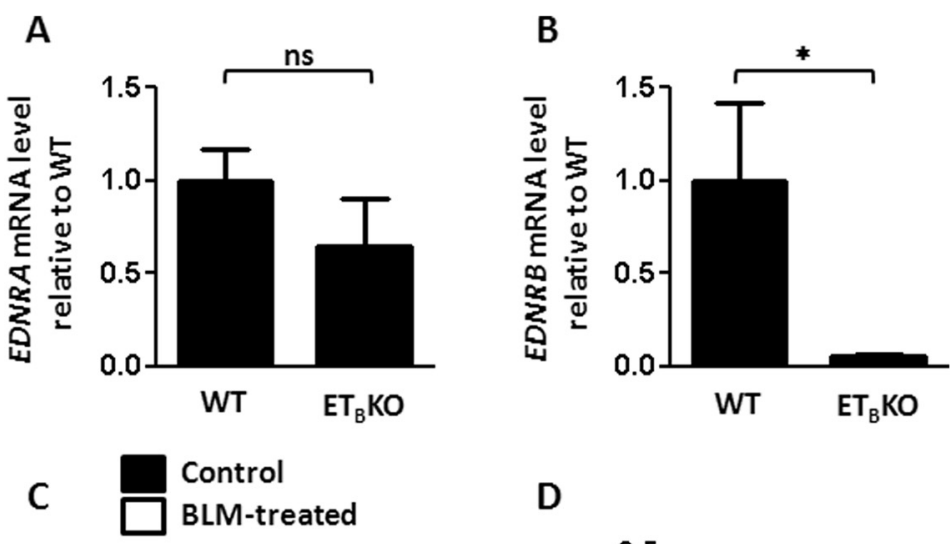

D
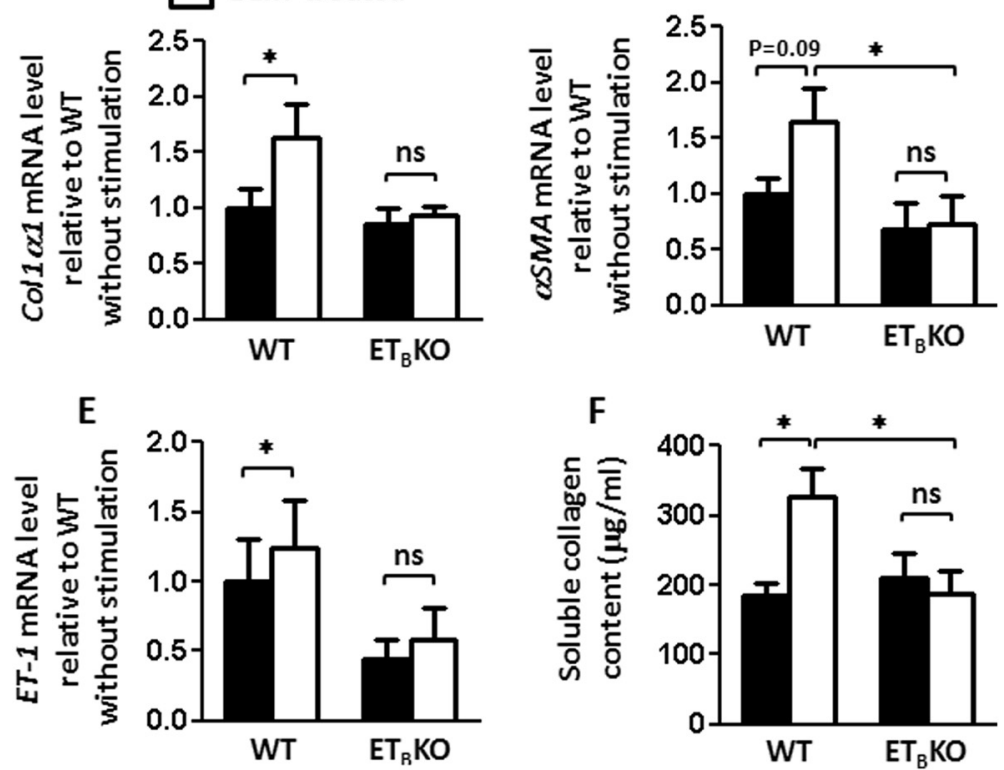

Fig. 5 Knockout of the $E_{B}$ receptor signal reduces the activation of skin-derived fibroblasts in response to BLM. a EDNRA and $\mathbf{b} E D N R B$ mRNA levels in skin-derived fibroblasts from WT and $\mathrm{ET}_{B} \mathrm{KO}$ mice $\left(n=5\right.$ each). $\mathbf{c}$-e BLM-induced fibroblast activation in $W T$ and $E T_{B} K O$ mice $(n=6-9$ each), determined by the gene expression levels of Col1a1, aSMA, and ET-1. Values show the mean mRNA levels relative to WT without stimulation ( $\left.{ }^{*} p<0.05\right)$. f Soluble collagen production from $W T$ and $\mathrm{ET}_{\mathrm{B}} \mathrm{KO}\left(\mathrm{n}=4\right.$ each) fibroblasts with or without BLM treatment $\left.{ }^{*} p<0.05\right)$. WT wild-type, aSMA a-smooth muscle actin, BLM bleomycin, Col1a1 collagen 1a1, ET-1 endothelin-1, ET ${ }_{B} K O$ endothelin type B receptor knockout, $P B S$ phosphate-buffered saline
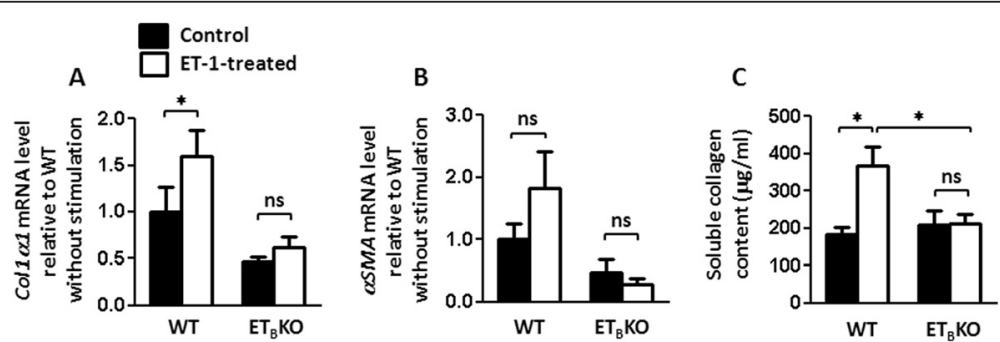

Fig. 6 Knockout of the $E_{B}$ receptor signal reduces the activation of skin-derived fibroblasts in response to ET-1. $\mathbf{a}$, $\mathbf{b} E T$-1-induced fibroblast activation in $W T$ and $E T_{B} K O$ mice ( $n=4$ or 5 each), determined by the gene expression levels of Col1a1, aSMA. Values show the mean mRNA levels relative to WT without stimulation $\left({ }^{*} p<0.05\right)$. c Soluble collagen production from WT and $\mathrm{ET}_{B} \mathrm{KO}\left(\mathrm{n}=4\right.$ each) fibroblasts with or without ET-1-treatment $\left(^{*} p<0.05\right)$. aSMA a-smooth muscle actin, BLM bleomycin, Col1a1 collagen 1a1, ET-1 endothelin-1, $E T_{B} K O$ endothelin type B receptor knockout, PBS phosphatebuffered saline, WT wild-type 
Next, we measured soluble collagen content in the supernatant with Sircol collagen assay to assess whether BLM or ET-1 stimulation increases collagen production by fibroblasts. BLM or ET-1 treatment of WT fibroblasts significantly induced collagens. Increase in collagen production by BLM or ET-1 stimulation was not seen in $\mathrm{ET}_{\mathrm{B}} \mathrm{KO}$ fibroblasts (Figs. $5 \mathrm{f}$ and $6 \mathrm{c}$ ). Collectively, $\mathrm{ET}_{\mathrm{B}} \mathrm{KO}$ fibroblasts showed less profibrotic properties in response to BLM or ET-1 than WT.

\section{Discussion}

In this study, we demonstrated for the first time with genetic $\mathrm{ET}_{\mathrm{B}} \mathrm{KO}$ mice that $\mathrm{ET}_{\mathrm{B}}$ receptor signaling in the presence of the $\mathrm{ET}_{\mathrm{A}}$ receptor promotes fibrosis in BLMinduced scleroderma. Myofibroblast formation was inhibited in $\mathrm{ET}_{\mathrm{B}} \mathrm{KO}$ mice, allowing them to resist BLM-induced skin fibrosis. At least one mechanism of the $\mathrm{ET}_{\mathrm{B}}$ receptor appears to function through dermal fibroblasts, because the $\mathrm{ET}_{\mathrm{B}} \mathrm{KO}$ fibroblasts did not respond to BLM or ET-1 stimulation, whereas WT fibroblasts showed increased Col1 $\alpha 1$ and $\alpha S M A$ expression in vitro.

Rescued $\mathrm{ET}_{\mathrm{B}} \mathrm{KO}$ rats and mice, like those used in this study, are useful for investigating $\mathrm{ET}_{\mathrm{B}}$ receptor signaling. $\mathrm{ET}_{\mathrm{B}} \mathrm{KO}$ rats show deteriorating health due to hypoxiainduced pulmonary hypertension, and $\mathrm{ET}_{\mathrm{B}} \mathrm{KO}$ mice show worsened vascular remodeling in a carotid artery ligation model $[27,28]$. Our study is the first to demonstrate that the $\mathrm{ET}_{\mathrm{B}}$ receptor is critical for BLM-induced scleroderma using $\mathrm{ET}_{\mathrm{B}} \mathrm{KO}$ mice.

ET-1 is important in fibrosis because it induces collagen production and myofibroblasts. We found that in WT fibroblasts, BLM induced ET-1, which in turn induced collagen production. On the other hand, $\mathrm{ET}_{\mathrm{B}} \mathrm{KO}$ fibroblasts did not produce collagen when stimulated by ET-1, indicating that $\mathrm{ET}_{\mathrm{B}}$ is indispensable for the ET-1induced collagen production. Thus, the ET-1-ET $\mathrm{E}_{\mathrm{B}}$ system is critical for the collagen production by fibroblasts.

We showed that myofibroblast formation was strongly inhibited in the $\mathrm{ET}_{\mathrm{B}} \mathrm{KO}$ mice in vivo. In addition, $\mathrm{ET}_{\mathrm{B}} \mathrm{KO}$ fibroblasts did not express $\alpha S M A$ mRNA in response to BLM or ET-1. These results indicate that $\mathrm{ET}_{\mathrm{B}}$ is involved in myofibroblast formation. In our experiments, ET-1's induction of $\alpha S M A$ in WT fibroblasts in vivo was stronger than that in vitro. This was not surprising, because there are multiple sources of myofibroblasts in vivo, including tissue-resident fibroblasts [29], epithelial or endothelial cells transitioning into mesenchymal cells (EMT or EndoMT) [30-33], or bone marrow-derived circulating fibrocytes $[34,35]$. Thus, we believe that $\mathrm{ET}_{\mathrm{B}}$ is involved in myofibroblast formation from various types of cells.

Myofibroblast precursors differ in various tissues. For example, resident fibroblasts are the main contributors to myofibroblasts in lung fibrosis [36], and hepatic stellate cells are the most important source of myofibroblasts in liver fibrosis [37]. Although a recent study found that adipocytes differentiate into myofibroblasts in dermal fibrosis [38], the primary source of myofibroblasts in dermal fibrosis remains unclear. $\mathrm{ET}_{\mathrm{B}}$ receptor signaling seems to be important in liver and cardiac fibrosis [39-41], but not renal fibrosis [42]. The difference of the skin and lung fibrosis might come from the difference in both myofibroblast precursor and contribution of $\mathrm{ET}_{\mathrm{B}}$ receptor signaling in the organ. Further investigation is needed to reveal which cells are responsible for generating dermal myofibroblasts, and how the $\mathrm{ET}_{\mathrm{A}}$ and $\mathrm{ET}_{\mathrm{B}}$ receptors are involved in dermal or other organ fibrogenesis.

In dermal fibroblasts, both $\mathrm{ET}_{\mathrm{A}}$ and $\mathrm{ET}_{\mathrm{B}}$ receptor signaling are reported to be necessary for ET-1 to exert its profibrotic effect [12]; in that study, neither $\mathrm{ET}_{\mathrm{A}}$ nor $\mathrm{ET}_{\mathrm{B}}$ receptor selective antagonists inhibited the collagen synthesis in dermal fibroblasts stimulated with ET-1. Our data appear to conflict with that study; this discrepancy might be due to differences between a pharmacological blockade and genetic knockout. The genetic knockout is assumed to affect permanently and completely, while the effect of pharmacological blockade is usually temporary and depends on affinity. We did not perform in vivo and in vitro study with the $\mathrm{ET}_{\mathrm{B}}$ selective antagonist, because it was reported that existing inhibitors could not suppress the fibroblast activation in vitro as mentioned above. We hope that new $\mathrm{ET}_{\mathrm{B}}$ selective antagonists that suppress fibroblast function will be developed.

Clinically, dual $\mathrm{ET}_{\mathrm{A}} / \mathrm{ET}_{\mathrm{B}}$ receptor antagonists (bosentan, macitentan) and a selective $\mathrm{ET}_{\mathrm{A}}$ receptor antagonist (ambrisentan) improve the hemodynamics, exercise capacity, and survival rate in patients with pulmonary arterial hypertension [9-11]. These ET receptor blockers are also effective for preventing and improving digital ulcers in SSc patients $[43,44]$. Currently, there is no selective $\mathrm{ET}_{\mathrm{B}}$ receptor antagonist that can be safely administered to humans. However, our study suggests that $\mathrm{ET}_{\mathrm{B}}$ receptor blockade is a potential pharmaceutical treatment for progressive skin fibrosis in SSc patients.

\section{Conclusions}

This study described that $\mathrm{ET}_{\mathrm{B}} \mathrm{KO}$ mice were resistant to BLM-induced skin sclerosis and that $\mathrm{ET}_{\mathrm{B}} \mathrm{KO}$ mice showed less fibroblast activation and myofibroblast formation in response to BLM or ET- 1 . Thus, ET-1-ET receptor signaling is involved in skin sclerosis and in collagen synthesis by dermal fibroblasts.

\section{Additional file}

Additional file 1: Figure S1. BLM-induced lung inflammation and fibrosis of WT and $\mathrm{ET}_{\mathrm{B}} \mathrm{KO}$ mice. (A) Total cell, (B) macrophages, (C) neutrophils, and (D) lymphocytes counts in BALF collected from WT and ET $\mathrm{K} K O$ with PBS or 
BLM treatment ( $\mathrm{n}=5-10$ mice per group) on day 28 after osmotic implantation ( $\left.{ }^{*} p<0.05\right)$. (E) Representative images of lung sections stained with Masson's trichrome at $40 \times$ magnification. (F) Ashcroft score of WT and $\mathrm{ET}_{\mathrm{B}} \mathrm{KO}$ mice with PBS or BLM treatment ( $\mathrm{n}=5-10$ mice per group) $\left.{ }^{*} p<0.05\right)$. $B L M$ bleomycin, $E T_{B} K O$ endothelin type $B$ receptor knockout, $P B S$ phosphatebuffered saline, WT wild- type. (TIF $1160 \mathrm{~kb}$ )

\section{Abbreviations}

aSMA: alpha-smooth muscle actin; BALF: bronchoalveolar fluid lavage; BLM: bleomycin; BSA: bovine serum albumin; cDNA: complementary DNA; Col1a1: collagen 1a1; DMEM: Dulbecco's modified Eagle's medium; $\mathrm{D} \beta \mathrm{H}$ : human dopamine $\beta$-hydroxylase; EDNRA: endothelin receptor type $A$; EDNRB: endothelin receptor type $B$; ET-1: endothelin-1; $E T_{A}$ : endothelin type $A$; $\mathrm{ET}_{\mathrm{B}}$ : endothelin type $\mathrm{B} ; \mathrm{ET}_{\mathrm{B}} \mathrm{KO}$ : endothelin type $\mathrm{B}$ receptor-knockout; FBS: fetal bovine serum; GAPDH: glyceraldahyde-3-phosphate dehydrogenase; PBS: phosphate-buffered saline; PCR: polymerase chain reaction; SEM: standard error of the mean; SSc: systemic sclerosis; WT: wild-type.

\section{Competing interests}

The authors declare that they have no competing interests.

\section{Authors' contributions}

KA carried out most of the experiments and drafted the manuscript. JS participated in the conception and design of the experiments, performed analysis and interpretation of data, and helped to draft the manuscript. SS and KN carried out the acquisition of the data, performed analysis and interpretation of the data, and helped to draft the manuscript. TO and KY carried out the acquisition of the data, performed analysis and interpretation of the data, and critically revised the manuscript. MY developed $\mathrm{ET}_{\mathrm{B}} \mathrm{KO}$ mice used in this study and provided them, participated in the conception of the experiments, and critically revised the manuscript. NE participated in the conception and design of the experiments, performed interpretation of the data, and critically revised the manuscript. AM conceived of the study, participated in its design and coordination, performed analysis and interpretation of the data, and helped to draft the manuscript. All authors read and approved the final manuscript.

\section{Acknowledgements}

The authors thank Shino Tanaka for providing technical assistance.

\section{Author details}

'Department of Rheumatology and Clinical Immunology, Kobe University Graduate School of Medicine, 7-5-1, Kusunoki-cho, Chuo-ku, Kobe 650-0017, Japan. ${ }^{2}$ Department of Clinical Pharmacy, Kobe Pharmaceutical University, Kobe, Japan. ${ }^{3}$ Division of Cardiovascular Medicine, Department of Internal Medicine, Kobe University Graduate School of Medicine, Kobe, Japan. ${ }^{4}$ International Institute for Integrative Sleep Medicine (WPI-IIIS), University of Tsukuba, Tsukuba, Japan

Received: 16 December 2015 Accepted: 3 May 2016

Published online: 21 May 2016

\section{References}

1. Ho YY, Lagares D, Tager AM, Kapoor M. Fibrosis-a lethal component of systemic sclerosis. Nat Rev Rheumatol. 2014;10:390-402.

2. Yamamoto T, Takagawa S, Katayama I, Yamazaki K, Hamazaki Y, Shinkai H, et al. Animal model of sclerotic skin. I: Local injections of bleomycin induce sclerotic skin mimicking scleroderma. J Invest Dermatol. 1999;112:456-62.

3. Batteux F, Kavian N, Servettaz A. New insights on chemically induced animal models of systemic sclerosis. Curr Opin Rheumatol. 2011;23:511-8.

4. Lagares D, García-Fernández RA, Jiménez CL, Magán-Marchal N, Busnadiego $\mathrm{O}$, Lamas $\mathrm{S}$, et al. Endothelin 1 contributes to the effect of transforming growth factor beta1 on wound repair and skin fibrosis. Arthritis Rheum. 2010;62:878-89.

5. Morelli S, Ferri C, Polettini E, Bellini C, Gualdi GF, Pittoni V, et al. Plasma endothelin-1 levels, pulmonary hypertension, and lung fibrosis in patients with systemic sclerosis. Am J Med. 1995;99:255-60.

6. Abraham DJ, Vancheeswaran R, Dashwood MR, Rajkumar VS, Pantelides P, Xu SW, et al. Increased levels of endothelin-1 and differential endothelin type $A$ and $B$ receptor expression in scleroderma-associated fibrotic lung disease. Am J Pathol. 1997;151:831-41.

7. Makino K, Jinnin M, Aoi J, Kajihara I, Makino T, Fukushima S, et al. Knockout of endothelial cell-derived endothelin-1 attenuates skin fibrosis but accelerates cutaneous wound healing. PLoS One. 2014;9:e97972.

8. Miyauchi T, Masaki T. Pathophysiology of endothelin in the cardiovascular system. Annu Rev Physiol. 1999;61:391-415.

9. Rubin LJ, Badesch DB, Barst RJ, Galie N, Black CM, Keogh A, et al. Bosentan therapy for pulmonary arterial hypertension. N Engl J Med. 2002;346:896-903.

10. Galiè N, Olschewski H, Oudiz RJ, Torres F, Frost A, Ghofrani HA, et al. Ambrisentan for the treatment of pulmonary arterial hypertension: results of the ambrisentan in pulmonary arterial hypertension, randomized, double-blind, placebo-controlled, multicenter, efficacy (ARIES) study 1 and 2. Circulation. 2008;117:3010-9.

11. Pulido T, Adzerikho I, Channick RN, Delcroix M, Galiè N, Ghofrani HA, et al. Macitentan and morbidity and mortality in pulmonary arterial hypertension. N Engl J Med. 2013;369:809-18.

12. Shi-Wen X, Denton CP, Dashwood MR, Holmes AM, Bou-Gharios G, Pearson JD, et al. Fibroblast matrix gene expression and connective tissue remodeling: role of endothelin-1. J Invest Dermatol. 2001;116:417-25.

13. Gariepy CE, Williams SC, Richardson JA, Hammer RE, Yanagisawa M. Transgenic expression of the endothelin-B receptor prevents congenital intestinal aganglionosis in a rat model of Hirschsprung disease. J Clin Invest. 1998;102:1092-101.

14. Rice J, Doggett B, Sweetser DA, Yanagisawa H, Yanagisawa M, Kapur RP. Transgenic rescue of aganglionosis and piebaldism in lethal spotted mice. Dev Dyn. 2000;217:120-32

15. Gariepy CE, Ohuchi T, Williams SC, Richardson JA, Yanagisawa M. Salt-sensitive hypertension in endothelin-B receptor-deficient rats. J Clin Invest. 2000;105:925-33.

16. Baynash AG, Hosoda K, Giaid A, Richardson JA, Emoto N, Hammer RE, et al. Interaction of endothelin-3 with endothelin-B receptor is essential for development of epidermal melanocytes and enteric neurons. Cell. 1994;79:1277-85.

17. Hosoda K, Hammer RE, Richardson JA, Baynash AG, Cheung JC, Giaid A, et al. Targeted and natural (piebald-lethal) mutations of endothelin-B receptor gene produce megacolon associated with spotted coat color in mice. Cell. 1994;79:1267-76.

18. Puffenberger EG. Hosoda K, Washington SS, Nakao K, deWit D, Yanagisawa $M$, et al. A missense mutation of the endothelin- $B$ receptor gene in multigenic Hirschsprung's disease. Cell. 1994;79:1257-66.

19. Lee R, Reese C, Bonner M, Tourkina E, Hajdu Z, Riemer EC, et al. Bleomycin delivery by osmotic minipump: similarity to human scleroderma interstitial lung disease. Am J Physiol Lung Cell Mol Physiol. 2014;306:L736-48.

20. Harrison Jr JH, Lazo JS. High dose continuous infusion of bleomycin in mice: a new model for drug-induced pulmonary fibrosis. J Pharmacol Exp Ther. 1987;243:1185-94.

21. Aono Y, Kishi M, Yokota Y, Azuma M, Kinoshita K, Takezaki A, et al. Role of platelet-derived growth factor/platelet-derived growth factor receptor axis in the trafficking of circulating fibrocytes in pulmonary fibrosis. Am J Respir Cell Mol Biol. 2014;51:793-801.

22. Ashcroft T, Simpson JM, Timbrell V. Simple method of estimating severity of pulmonary fibrosis on a numerical scale. J Clin Pathol. 1998;41:467-70.

23. Gallucci RM, Sloan DK, Heck JM, Murray AR, O'Dell SJ. Interleukin 6 indirectly induces keratinocyte migration. J Invest Dermatol. 2004;122:764-72.

24. Abraham DJ, Eckes B, Rajkumar V, Krieg T. New developments in fibroblast and myofibroblast biology: implications for fibrosis and scleroderma. Curr Rheumatol Rep. 2007;9:136-43.

25. Desmouliere A, Chaponnier C, Gabbiani G. Tissue repair, contraction, and the myofibroblast. Wound Repair Regen. 2005;13:7-12.

26. Yamamoto T, Eckes B, Krieg T. Bleomycin increases steady-state levels of type I collagen, fibronectin and decorin mRNAs in human skin fibroblasts. Arch Dermatol Res. 2000;292:556-61.

27. Ivy D, McMurtry IF, Yanagisawa M, Gariepy CE, Le Cras TD, Gebb SA, et al. Endothelin B receptor deficiency potentiates ET-1 and hypoxic pulmonary vasoconstriction. Am J Physiol Lung Cell Mol Physiol. 2001;280:L1040-8.

28. Murakoshi N, Miyauchi T, Kakinuma Y, Ohuchi T, Goto K, Yanagisawa M, et al. Vascular endothelin-B receptor system in vivo plays a favorable inhibitory role in vascular remodeling after injury revealed by endothelin-B receptor-knockout mice. Circulation. 2002;106:1991-8.

29. Hinz B. Formation and function of the myofibroblast during tissue repair. J Invest Dermatol. 2007;127:526-37. 
30. Thiery JP, Acloque H, Huang RY, Nieto MA. Epithelial-mesenchymal transitions in development and disease. Cell. 2009;139:871-90.

31. Thiery JP, Sleeman JP. Complex networks orchestrate epithelialmesenchymal transitions. Nat Rev Mol Cell Biol. 2006;7:131-42.

32. Kalluri R, Neilson EG. Epithelial-mesenchymal transition and its implications for fibrosis. J Clin Invest. 2003;112:1776-84

33. Arciniegas $E$, Sutton $A B$, Allen $T D$, Schor AM. Transforming growth factor beta 1 promotes the differentiation of endothelial cells into smooth muscle-like cells in vitro. J Cell Sci. 1992;103:521-9.

34. Herzog EL, Bucala R. Fibrocytes in health and disease. Exp Hematol. 2010;38:548-56

35. Bellini A, Mattoli S. The role of the fibrocytes, a bone marrow-derived mesenchymal progenitor, in reactive and reparative fibroses. Lab Invest. 2007;87:858-70.

36. Tsukui T, Ueha S, Abe J, Hashimoto S, Shichino S, Shimaoka T, et al. Qualitative rather than quantitative changes are hallmarks of fibroblasts in bleomycin-induced pulmonary fibrosis. Am J Pathol. 2013;183:758-73.

37. Guyot C, Lepreux S, Combe C, Doudnikoff E, Bioulac-Sage P, Balabaud C, et al. Hepatic fibrosis and cirrhosis: the (myo)fibroblastic cell subpopulations involved. Int J Biochem Cell Biol. 2006;38:135-51.

38. Roberta GM, Benjamin DK, Jun W, Tammara AW, Lauren VG, Michael LW, et al Myofibroblasts in murine cutaneous fibrosis originate from adiponectinpositive intradermal progenitors. Arthritis Rheumatol. 2015;67:1062-73.

39. Rockey DC, Chung JJ. Endothelin antagonism in experimental hepatic fibrosis. Implications for endothelin in the pathogenesis of wound healing. J Clin Invest. 1996:98:1381-8.

40. Gandhi CR, Kuddus RH, Uemura T, Rao AS. Endothelin stimulates transforming growth factor-beta1 and collagen synthesis in stellate cells from control but not cirrhotic rat liver. Eur J Pharmacol. 2000;406:311-8.

41. Seccia TM, Belloni AS, Kreutz R, Paul M, Nussdorfer GG, Pessina AC, et al. Cardiac fibrosis occurs early and involves endothelin and AT-1 receptors in hypertension due to endogenous angiotensin II. J Am Coll Cardiol. 2003:19:666-73.

42. Kalk P, Rückert M, Godes M, von Websky K, Relle K, Neumayer HH, et al. Does endothelin $B$ receptor deficiency ameliorate the induction of peritoneal fibrosis in experimental peritoneal dialysis? Nephrol Dial Transplant. 2010:25:1474-8.

43. Matucci-Cerinic M, Denton CP, Furst DE, Mayes MD, Hsu VM, Carpentier P, et al. Bosentan treatment of digital ulcers related to systemic sclerosis: results from the RAPIDS-2 randomised, double-blind, placebo-controlled trial. Ann Rheum Dis. 2011;70:32-8.

44. Parisi S, Peroni CL, Laganà A, Scarati M, Ambrogio F, Bruzzone M, et al. Efficacy of ambrisentan in the treatment of digital ulcers in patients with systemic sclerosis: a preliminary study. Rheumatology (Oxford). 2013:52:1142-4.

\section{Submit your next manuscript to BioMed Central and we will help you at every step:}

- We accept pre-submission inquiries

- Our selector tool helps you to find the most relevant journal

- We provide round the clock customer support

- Convenient online submission

- Thorough peer review

- Inclusion in PubMed and all major indexing services

- Maximum visibility for your research

Submit your manuscript at www.biomedcentral.com/submit

) Biomed Central 